\title{
Analysis of Greenhouse Gas Reduction by Using Organic Fertilizer in Boyolali Regency
}

\author{
Etik Purnamasari $^{1 *}$, Sudarno Sudarno ${ }^{2}$ \\ ${ }^{1}$ Master Program of Environmental Science, School of Postgraduate Studies, Diponegoro University, Semarang - Indonesia \\ ${ }^{2}$ Doctoral Program of Environmental Science, School of Postgraduate, Diponegoro University, Semarang - Indonesia
}

\begin{abstract}
Agriculture contributes approximately $14 \%$ of greenhouse gases at global scale and $7 \%$ at national level. Fertilizer using urea is one of agriculture's activities that produces greenhouse gases. Indonesian government's commitment to reduce greenhouse emission by $26 \%$ in 2020 by establishing Rencana Aksi Nasional (National Action Plan) reducing greenhouse gases. In this National Act Plan, agricultural sector is obligated to reduce gas emission by $8 \mathrm{Gg} \mathrm{CO}_{2} \mathrm{e}$. This research aims to calculate greenhouse gas emission that is being produced by the using urea fertilizer in Boyolali Regency, as well as its mitigation plan. The result shows that the using organic fertilizer as the substitute of urea fertilizer can reduce greenhouse gas emission. The emission of greenhouse gas from using urea fertilizer in Boyolali Regency in the form of $\mathrm{CO}_{2}$ was 18,386 tons $\mathrm{CO}_{2}$, and in the form of $\mathrm{N}_{2} \mathrm{O}$ was 42,956 tons $\mathrm{CO}$ e. Meanwhile, the greenhouse gas emission from using organic fertilizer was only in the form of $\mathrm{N}_{2} \mathrm{O}$ as much as 48,575 tons CO2e. Overall, the use of organic fertilizer can reduce greenhouse gas emission by 12,768 $\mathrm{CO}_{2} \mathrm{e}$.
\end{abstract}

Keywords: Agriculture; Urea Fertilizer; Greenhouse Gas.

\section{Introduction}

Global warming caused by the increase of greenhouse gases in the atmosphere is considered the cause of climate change. The increase of greenhouse gas emissions has started since the industrial revolution and currently its concentration has been increasing due to human activities. The United Nations Framework Convention on Climate Change (UNFCCC) which is one of the agenda in the Rio de Janeiro Earth Summit in 1992 is commits to limit global temperature increases and the impact of climate change.

Indonesia as a member of the climate change convention has ratified the establishment of UNFCCC through Law No. 6 of 1994. Therefore, Indonesia is involved in fulfilling its obligations as stated in UNFCCC. One of its obligations is to build, update periodically, and provide national inventories of emissions by source and sink using a comparable methodology approved by the parties of the Convention.

Based on the guidelines of the Intergovernmental Panel on Climate Change (IPCC), the sources of emissions and sinks that are covered in the greenhouse gas inventory are 1) procurement and energy use; 2) industrial processes and use of products; 3) agriculture, forestry and other land uses and; 4) waste [1].
Greenhouse gases potentially cause climate change, especially $\mathrm{CO}_{2}, \mathrm{CH}_{4}$, and $\mathrm{N}_{2} \mathrm{O}$. The biggest concentration of the gas in the atmosphere is $\mathrm{CO}_{2}$, but it has the smallest Global Warming Potential (GWP), while $\mathrm{N}_{2} \mathrm{O}$ has the biggest potential for Global Warming Potential.

The participation of Indonesia in climate change mitigation is the statement of the Non-Binding Commitment by the President of the Republic of Indonesia at the G-20 meeting in Pittsburgh - USA on September 9, 2009. This Non-Binding Commitment includes commitment of Indonesian Government to reduce greenhouse gas emission by $26 \%$ by 2020 from local funding and up to $41 \%$ by 2020 from international funding [2]. Following up on the commitment, the Indonesian Government has established the Presidential Regulation (Perpres) No. 61 of 2011 on Rencana Aksi Nasional (National Action Plan) for Greenhouse Gases Reduction.

Agriculture contributes approximately $14 \%$ of greenhouse gas at global scale and $7 \%$ at national scale. Greenhouse gas emissions from agricultural are expected to increase along with increasing demand for food. The sources of greenhouse gas emissions from agricultural are 1) methane $\left(\mathrm{CH}_{4}\right)$ from rice cultivation; 2) carbon dioxide $\left(\mathrm{CO}_{2}\right)$ from using lime and urea

\footnotetext{
* Corresponding author : etikpurnamasari@gmail.com
} 
fertilizer; 3) nitrous oxide (Direct and Indirect $\mathrm{N}_{2} \mathrm{O}$ ) from manage soil and; 5) Non- $\mathrm{CO}_{2}$ from biomass burning. To solve the problem, agricultural sector is required to reduce gas emission by $8 \mathrm{Gg} \mathrm{CO}_{2} \mathrm{e}$ based on this National Action Plan.

Presidential Regulation No. 61 of 2011 on National Action Plan for Greenhouse Gases Reduction also mentions that the Governor should establish Rencana Aksi Daerah (Regional Action Plan) to reduce greenhouse gas emissions in each province. Before formulating the action plan, it is necessary to know the status of emission by source and sink from the existing potential sources in the area. This has been formulated in Presidential Regulation No. 71 of 2011 on The Inventories of National Greenhouse gases [2-4].

Central Java Province is one of the provinces in Indonesia that issues the Governor Regulation by Pergub No. 43 of 2012 on Regional Action Plan for Greenhouse Gases Reduction in 2010-2020. According to the Governor Regulation, the sources of agriculture emission in Central Java come from biomass burning, liming, urea fertilization, manage soil, and rice cultivation [5].

Table 1. Greenhouse gas emission of agricultute in Central Java

\begin{tabular}{|l|l|}
\hline \multicolumn{1}{|c|}{ Category } & $\begin{array}{c}\text { Greenhouse Gas } \\
\text { Emission (tons CO2e) }\end{array}$ \\
\hline Biomass burning & Not Calculated \\
\hline Liming & 33 \\
\hline Urea Fertilization & 642.154 \\
\hline Direct $\mathrm{N}_{2} \mathrm{O}$ from manage soil & 884.778 \\
\hline Indirect $\mathrm{N}_{2} \mathrm{O}$ from manage soil & 1.604 .360 \\
\hline Rice Cultivation & Not Calculated \\
\hline
\end{tabular}

Considering the emission source, Regional Action Plan has policy of controlling greenhouse gas emission from agriculture related to fertilizer application, by controlling and optimizing fertilizers and pesticides, and reuse agricultural and livestock waste as input of agricultural activities [5].

This research aims to calculate greenhouse gas emission that is produced by using urea fertilizer in Boyolali Regency, as well as its mitigation plan.

\section{Method}

This research was held in Boyolali Regency, Central Java Province. The data used was secondary data from Statistics of Boyolali Regency, that is Boyolali Regency in Figure 2017. The data used was harvested area of food crops. The data of urea fertilization was obtained through the recommendation dosage of urea fertilizer approach for each commodity.

Calculation method in this research used Tier 1 methods of IPCC Guidelines 2006. Tier 1 method calculates greenhouse gas emission by using basic equation and default emission factor (EF) provided in IPCC Guidelines. The calculation of greenhouse gas emissions covered calculation of $\mathrm{CO}_{2}$ emission and $\mathrm{N}_{2} \mathrm{O}$ emissions from the using of fertilizer.

\section{Result and Discussion}

\subsection{Total Usage of Urea Fertilizer}

Total usage of urea fertilizer of food crops in Boyolali Regency was 25,072 tons per year. The amount of urea fertilizer was calculated using an approach based on planting area and recommended dosage. The planting area data was the harvested area data, assuming the area of harvested area was the same as the planting area. Total usage of urea fertilizer was calculated by multiplying planting area and recommendation dosage.

Table 2. Recommendation dosage of urea fertilizer of food crops

\begin{tabular}{|l|c|}
\hline \multicolumn{1}{|c|}{ Commodities } & Urea Fertilizer (Kg/ha) \\
\hline Paddy & 250 \\
\hline Maize & 350 \\
\hline Soybean & 56 \\
\hline Peanut & 56 \\
\hline Mungbean & 56 \\
\hline Cassava & 150 \\
\hline Sweet Potato & 150 \\
\hline
\end{tabular}

The largest use of urea fertilizer was for paddy and maize commodities. Details of the usage of urea fertilizer of food crop sector in Boyolali Regency are as follows:

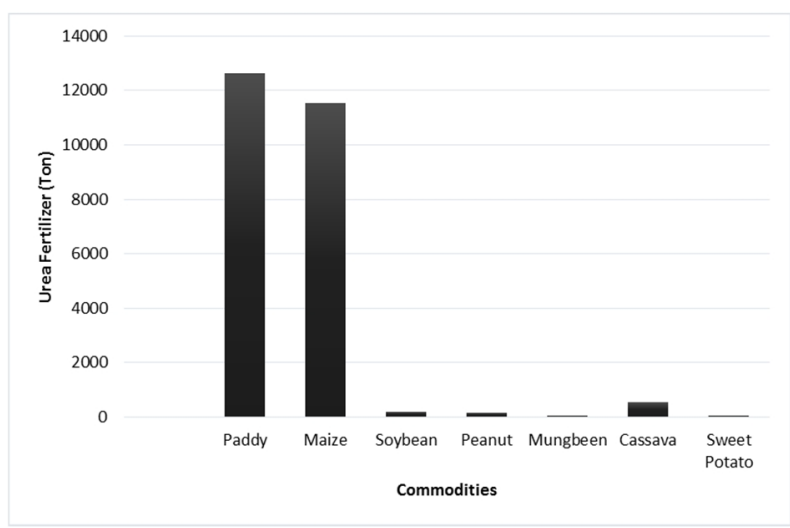

Fig 1. Urea fertilizer usage of food crops

The largest use of urea fertilizer was in the Andong, Wonosegoro, and Nogosari District. 


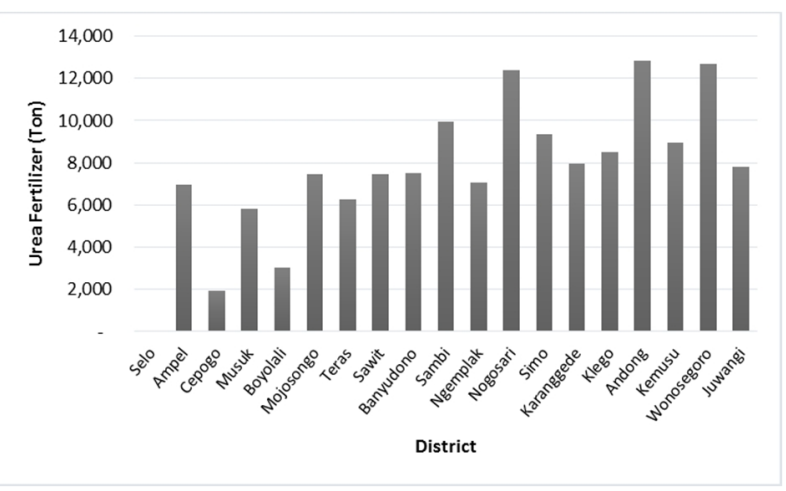

Fig. 2 Urea fertilizer usage of District in Boyolali

\subsection{Greenhouse Gas Emissions}

\subsection{1 $\mathrm{CO}_{2}$ Emission from Urea Fertilization}

Urea fertilization of agricultural causes the release of $\mathrm{CO} 2$ used during the manufacturing process of the urea at the plant, this emission is calculated as a sink in the industrial sector. Urea fertilizer $\left(\mathrm{CO}\left(\mathrm{NH}_{2}\right)_{2}\right)$ is converted to ammonium $\left(\mathrm{NH}_{4+}\right)$, hydroxyl ions $\left(\mathrm{OH}_{-}\right)$, and bicarbonate $\left(\mathrm{HCO}_{3}-\right)$ with the presence of water and urease enzymes. $\mathrm{CO}_{2}$ emission from using urea fertilizer is calculated by multiplying the amount of urea fertilizer usage per year and emission factor. Emission factor for urea fertilizer is 0,2 [1].

Table 3. $\mathrm{CO} 2$ emission of food crops

\begin{tabular}{|l|c|}
\hline \multicolumn{1}{|c|}{ Commodities } & CO$_{2}$ Emission (tons C/year) \\
\hline Paddy & 2.527 \\
\hline Maize & 2.308 \\
\hline Soybean & 41 \\
\hline Peanut & 29 \\
\hline Mungbean & 1 \\
\hline Cassava & 107 \\
\hline Sweet Potato & 1 \\
\hline Total & 5.014 \\
\hline
\end{tabular}

The result shows that the using of urea fertilizer produced $\mathrm{CO}_{2}$ emission by 5.014 tons $\mathrm{C}$ per year or 18.386 tons $\mathrm{CO}_{2}$ per year.

Nitrogen nutrient is the required elements in the most amount, called primary macro nutrients. Regarding by the content of nitrogen elements as nutrients needed by plants, the amount of organic fertilizer form manure as a substitute for urea fertilizer must be considered. To supply the same nitrogen nutrient, using 25,072 tons of urea fertilizer is proportional to 492,865 tons of manure fertilizer with $2.34 \%$ Nitrogen content.

\subsubsection{Direct $\mathrm{N}_{2} \mathrm{O}$ from manage soil}

The addition of Nitrogen containing fertilizers will increase nitrification-denitrification processes that can increase $\mathrm{N}_{2} \mathrm{O}$ emission. Direct $\mathrm{N}_{2} \mathrm{O}$ from manage soil is calculated by input from activity data of the total amount of Nitrogen fertilizer both organic and inorganic applied to the farm. This research aims to compare the emission of $\mathrm{N}_{2} \mathrm{O}$ from using urea fertilizer and manure fertilizer. Things to consider in the calculation is the separation of fertilizer use for wetlands or paddy fields and dry land, because $\mathrm{N}_{2} \mathrm{O}$ emission factor which is resulted from nitrification and denitrification process is different between wetlands and drylands.

The result obtained show direct $\mathrm{N}_{2} \mathrm{O}$ emission from the application of urea fertilizer and manure fertilizer is the same

- Direct $\mathrm{N}_{2} \mathrm{O}$ of urea fertilizer

$\begin{array}{lrl}\text { Fertilizer Applied } & 25,072 \text { tons } \\ \mathrm{N}_{2} \mathrm{O} \text { Emission } & 77 \text { tons } \mathrm{N} / \text { year } \\ \mathrm{N}_{2} \mathrm{O} \text { Emission } & 120 \text { tons } \mathrm{N}_{2} \mathrm{O} / \text { year } \\ \mathrm{CO}_{2} \text { Emission } & 37,338 \text { tons } \mathrm{CO}_{2} \mathrm{e} / \text { year }\end{array}$

- Direct $\mathrm{N}_{2} \mathrm{O}$ of manure fertilizer

$\begin{array}{lr}\text { Fertilizer Applied } & 492,865 \text { tons } \\ \mathrm{N}_{2} \mathrm{O} \text { Emission } & 77 \text { tons } \mathrm{N} / \text { year } \\ \mathrm{N}_{2} \mathrm{O} \text { Emission } & 120 \text { tons } \mathrm{N}_{2} \mathrm{O} / \text { year } \\ \mathrm{CO}_{2} \text { Emission } & 37,338 \text { tons } \mathrm{CO}_{2} \mathrm{e} / \text { year }\end{array}$

\subsubsection{Indirect $\mathrm{N}_{2} \mathrm{O}$ from manage soil}

The application of Nitrogen fertilizer in the soil also produces indirect $\mathrm{N}_{2} \mathrm{O}$ emission from volatilization of $\mathrm{NH}_{3}$ and $\mathrm{NO}_{\mathrm{x}}$ from the soil then these gases and the products of nitrate and nitrite are deposited back into the soil and water. Indirect $\mathrm{N}_{2} \mathrm{O}$ emission from manage soil is based on the volatility $\mathrm{N}$ deposition fraction, so there is no need to differentiate wetlands or drylands. The volatility $\mathrm{N}$ deposition fraction is different between inorganic fertilizer and organic fertilizer.

The result shows that direct $\mathrm{N}_{2} \mathrm{O}$ emission from application of manure fertilizer is as twice as the application of urea fertilizer.

- Indirect $\mathrm{N}_{2} \mathrm{O}$ of urea fertilizer

$\begin{array}{lr}\text { Fertilizer Applied } & 25.072 \text { tons } \\ \mathrm{N}_{2} \mathrm{O} \text { Emission } & 12 \text { tons } \mathrm{N} / \text { year } \\ \mathrm{N}_{2} \mathrm{O} \text { Emission } & 18 \text { tons } \mathrm{N}_{2} \mathrm{O} / \text { year } \\ \mathrm{CO}_{2} \text { Emission } & 5.618 \text { tons } \mathrm{CO}_{2} \mathrm{e} / \text { year }\end{array}$

- Indirect $\mathrm{N}_{2} \mathrm{O}$ of manure fertilizer
Fertilizer Applied
492.865 tons
$\mathrm{N}_{2} \mathrm{O}$ Emission
$\mathrm{N}_{2} \mathrm{O}$ Emission
23 tons $\mathrm{N} /$ year
36 tons $\mathrm{N}_{2} \mathrm{O} /$ year
$\mathrm{CO}_{2}$ Emission
11.236 tons $\mathrm{CO}_{2} \mathrm{e} /$ year

\subsection{Comparison of greenhouse gas emissions between the application of urea fertilizer and organic fertilizer}

Greenhouse gas emissions from application of urea fertilizer was 61,342 tons $\mathrm{CO}_{2} \mathrm{e}$ per year, and can be reduce by 12,768 tons $\mathrm{CO}_{2} \mathrm{e}$ per year by application manure fertilizer. Overall, greenhouse gas emissions 
from the application of urea fertilizer were higher than the application of manure fertilizer. This is because greenhouse gas emission in the form of $\mathrm{CO}_{2}$ is produced only from fertilization using urea fertilizer. However, viewed from other forms of greenhouse gas emissions, manure fertilizer contributes more greenhouse gas emission in the form of $\mathrm{N}_{2} \mathrm{O}$.

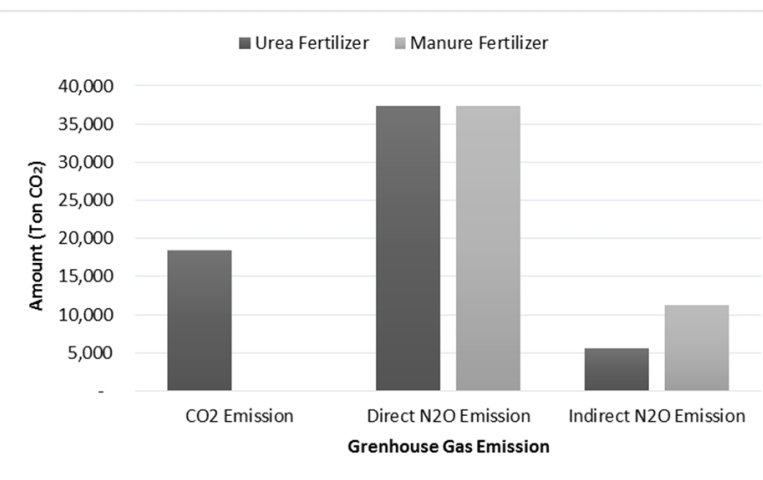

Fig. 1 Comparison of greenhouse gas emissions between urea fertilizer and organic fertilizer

\subsection{Advantages and Constraints of using Manure Fertilizer}

Livestock production systems have various effects on the environment. Most of these effects are related to emissions of nitrogen from organic manures into the environment $[6,7]$. The use of livestock and poultry manures to produce bio-fuels is one of most effective solutions to avoid serious environmental problems while fulfilling increasing energy demand [8,9]. Livestock manure can also be used as organic fertilizer. Manure is a source of some nutrients such as nitrogen, phosphorus, potassium, and others [10]. Nitrogen required by plants can be found by application of manure fertilizer. Nitrogen from manure fertilizer is generally converted to available nitrate form. Nitrate will be easily soluble and move into the roots of the plant.

This form is similar to the form that plants can extract from inorganic fertilizer sources. In addition to filling the nitrogen, manure fertilizer can improve the chemical, physical, and biological quality of the soil. Manure fertilizer can Improve soil fertility, including supporting soil $\mathrm{pH}$, increasing the exchange ion, reducing metal elements and harmful organic acids, improving the structure, porosity, and pore soil [11].

Nutrient content of manure is different, depending on the type of livestock and management of the manure. To maximize the use of fertilizer, manure must be composted to become compost manure with $\mathrm{C} / \mathrm{N}$ ratio below $20 \%$ [12]. In addition to $\mathrm{C} / \mathrm{N}$ ratio, using manure directly is also associated with high water content. Manure with high water content will be difficult to apply.

The highest nitrogen content is found in compost fertilizer with basic material of cattle manure, that is $2,34 \%$. With high Nitrogen content, it is possible to compost cattle manure as organic fertilizer as a source of nitrogen for plants. The nutrient contents of manure fertilizer after being composted is as follows [13]:

Table 4. The nutrients content of manure fertilizer

\begin{tabular}{|l|c|c|c|}
\hline \multirow{2}{*}{ Livestock } & \multicolumn{3}{c|}{ Nutrients (\%) } \\
\cline { 2 - 4 } & N & P & K \\
\hline Cattle & 2,34 & 1,08 & 0,69 \\
\hline Sheep & 1,85 & 1,14 & 2,49 \\
\hline Chicken & 1,70 & 2,12 & 1,45 \\
\hline
\end{tabular}

In term of the economic point of view, the use of organic fertilizer can reduce production costs. The cost of fertilizer in the paddy farming cultivation ranges between Rp 621,000 - Rp 733,000 per hectare, and this potentially saves the cost of fertilizer by $18.14 \%$ $19.48 \%$ through integrated agriculture [14]. The cost of fertilizer can be eliminated if all inorganic fertilizers are replaced with self-made manure fertilizer by utilizing livestock waste.

Boyolali Regency is one of the largest cattle producers in Central Java. The population of cattle in Central Java is 89,844 dairy cattles and 95,651 beef cattles [15]. A cattle can produce around $3 \mathrm{~kg}$ of dirt per day and $40 \%$ depreciation in composting [10]. Based on the calculation, the amount of cattle manure is 81,247 tons per year. This amount is not enough if all agriculture cultivation of food crop in Boyolali Regency switches to manure fertilizer. The anticipation is to utilize the source of material from other livestock such as buffalo, horse, goat, and chicken, by always considering the nitrogen content needed by plants.

The use of manure fertilizer can increase production by specific management, such as System of Rice Intensification. System of rice intensification is one of the approaches in rice cultivation that emphasizes the management of land, plants and water, through the empowerment of group and local wisdom based on environmentally friendly activities. Management of rice cultivation using the system of rice intensification conducted in Garut Regency and Ciamis Regency has been able to increase production compared to conventional paddy management. The harvest obtained using the system of rice intensification is around 5-7 tons per hectare, while conventional paddy management obtains around 4-5 tons per hectare [16].

Despite many advantages from using manure fertilizer as a substitute for urea fertilizer, not all farmers apply it because they are worried about the risk when switching to manure fertilizer. The increase of harvest could only be experienced by the farmers that had applied system of rice intensification in more than two seasons. For beginning farmers who still use urea fertilizer, they generally experience the decrease of harvest. Moreover, the lack of manure fertilizer has become the problem [16]. To overcome the problem, intensive briefing is needed to persuade the farmers to switch into organic fertilizer. 
Intensive briefing has been proved to be influencing on farmers acceptance of the idea $[17,18]$. Thus, the intensity of the briefing need to be added. It can be predicted that describing the advantages of using organic fertilizer in terms of production, income, and environment will have a big influence on changing farmer's attitude toward the using of organic fertilizer.

\section{Conclusion}

The reduction of greenhouse gas emissions due to the use of organic fertilizer is possible through the application of manure fertilizer by paying attention to total nitrogen content of the fertilizer. The potential of reducing greenhouse gas emission from the application of manure fertilizer is 12,768 tons $\mathrm{CO}_{2}$ e per year $(0.14 \%$ per hectare).

The use of organic fertilizer will produce higher $\mathrm{N}_{2} \mathrm{O}$ emission than the use of urea fertilizer, but overall the use of urea fertilizer produces more greenhouse gases. The emissions of greenhouse gas from using urea fertilizer in the form of $\mathrm{CO}_{2}$ was 18,386 tons $\mathrm{CO}_{2}$, and in the form of $\mathrm{N}_{2} \mathrm{O}$ was 42,956 tons $\mathrm{CO} 2 \mathrm{e}$. Meanwhile, the greenhouse gas emissions from using organic fertilizer in the form of $\mathrm{N}_{2} \mathrm{O}$ was 48,575 tons $\mathrm{CO} 2 \mathrm{e}$.

\section{References}

1. Inter-governmental Panel on Climate Change. IPCC Guidelines for National Greenhouse Gas Inventories (2006)

2. Ariani. M, Setyanto. P, Ardiansyah. M, Biaya Pengurangan (Marginal Abatement Cost) Emisi Gas Rumah Kaca (GRK) Sektor Pertanian di Kabupaten Grobogan dan Tanjung Jabung Timur. Jurnal Ilmu Lingkungan, 14(1), 39-49 (2006)

3. Peraturan Presiden. Rencana Aksi Nasional Penurunan Emisi Gas Rumah Kaca (GRK) Nasional. Pemerintah Indonesia (2011)

4. Peraturan Presiden. Penyelenggaraan Inventarisasi GRK oleh Pemerintah Pusat, Provinsi dan Kab/Kota. Pemerintah Indonesia (2011)

5. Peraturan Gubernur. Rencana Aksi Daerah Penurunan Emisi Gas Rumah Kaca Provinsi Jawa Tengah 2010-2020 (2012)

6. Haase, M., Rösch, C., \& Ulrici, O. Feasibility study on the processing of surplus livestock manure into an organic fertilizer by thermal concentration-The case study of Les Plenesses in Wallonia. Journal of Cleaner Production, 161, 896-907 (2017)

7. Loyon, L., Burtons, C. H., Misselbrook, T., Webb, J., Philippe, F. X., Aguilar, M., ... \& Bonmati, A. Best available technology for European livestock farms: Availability, effectiveness and uptake. Journal of environmental management, 166, 1-11 (2016)

8. Tsai. W. T, \& Liu. S. C, Thermochemical characterization of cattle manure relevant to its energy conversion and environmental implications. Biomass Conversion and Biorefinery, 6(1), 71-77 (2016)

9. Xin, Y., Wang, D., Li, X. Q., Yuan, Q., \& Cao, H. Influence of moisture content on cattle manure char properties and its potential for hydrogen rich gas production. Journal of Analytical and Applied Pyrolysis, 130, 224-232 (2018)

10. Hartatik. W, Widowati. L. R, Pupuk kandang. Pupuk organik dan pupuk hayati (2006)

11. Setyorini. D, Pupuk organik tingkatkan produksi pertanian. Warta Penelitian dan Pengembangan Pertanian Pusat Penelitian Tanah dan Agroklimat. 27(6): 13-15 (2005)

12. Badan Penelitian dan Pengembangan Pertanian. Sistem Pertanian Organik Mendukung Produktivitas Lahan Berkelanjutan. Bogor (2015)

13. Badan Penelitian dan Pengembangan Pertanian. Pupuk Organik dan Pupuk Hayati. Bogor (2006)

14. Kariyasa. K, Sistem integrasi tanaman-ternak dalam perspektif reorientasi kebijakan subsidi pupuk dan peningkatan pendapatan petani. Analisis Kebijakan Pertanian, 3(1), 68-80 (2017).

15. Badan Pusat Statistik. Boyolali in Figure. Boyolali (2017)

16. Anugrah. I. S, Sumedi. S, Wardana. I. P, Gagasan dan implementasi System of Rice Intensification (SRI) dalam kegiatan budidaya padi ekologis (BPE). Analisis Kebijakan Pertanian, 6(1), 75-99 (2016)

17. Suprapto. E, Analisis faktor-faktor yang mempengaruhi usahatani padi organik di Kabupaten Sragen. Doctoral dissertation Sebelas Maret University (2010)

18. Widowati. E, Analisis Ekonomi Usahatani Padi Organik Di Kabupaten Sragen. Jurnal Ilmu Ekonomi dan Pembangunan, 6(1). (2007). 